\title{
A moral price for medicine
}

\author{
Gabriel Wong ${ }^{1}$, Lawrence $\underline{\operatorname{Tan}}^{1}$, MRCP, Philip Yap ${ }^{1}$, MRCP
}

\section{INTRODUCTION}

In his seminal text 'The Gift Relationship', Richard Titmuss famously contrasted voluntary and commercial systems of blood donation. ${ }^{(1)}$ His conclusion that an altruistic system was superior immediately drew criticism from famed economist Kenneth Arrow, who argued that a commercial system provided more choice since hospitals and patients can choose from both commercial and voluntary sources, noting flaws in Titmuss' epistemology and methodology. ${ }^{(2)}$ Even philosopher Peter Singer, in a defence of Titmuss, acknowledged the role of a pricing system in alleviating an acute shortage of blood in Korea. ${ }^{(3)}$

Medical services are more complex than blood donation. Hence, determining a fair price is a practice that has been fraught with controversy. India fined the drug company Novartis for allegedly overcharging for its painkiller Voveran. ${ }^{(4)}$ Singapore's medical statutory board fined and suspended surgeon Susan Lim for overcharging the Bruneian royalty. ${ }^{(5)}$ The case was highly controversial as the Singapore Medical Council determined that there was an unstated 'ethical limit' to the prices of medical services $^{(6)}$, to the chagrin of some who viewed this limit as amorphous and arbitrary. This paper seeks to explore the pros and cons of the free market in regulating healthcare pricing and discuss whether there can be a fair and ethical price for medicine.

\section{MORALITY OF THE MARKETS}

Capitalism's central tenet is that the collective pursuit of selfinterest can result in efficient allocation of resources. Selfinterest is expressed through the pursuit of utility to maximise an individual's welfare, which is determined by satisfaction derived from consuming a good and contributions to the utility of others. This pursuit is constrained by an implicit social contract in which the individual works to improve the utility of all. ${ }^{(2}$ In the free market, self-interest compels both consumers and producers to respond to price signals, which will determine the value individuals ascribe to a good and the costs of producing that good. This model assumes that both parties in the economic transaction are able to make an informed decision based on an accurate cost-benefit analysis.

The free market is generally defended on utilitarian grounds since it theoretically maximises welfare. Political philosopher John Gray argues that it "harnesses human imperfections in the service of human welfare" ${ }^{(7)}$ Libertarians further add that a free market, where buyers and sellers are free to price according to demand and supply factors, is important for liberty. Liberty, as John Stuart Mill famously argued, is important in maximising welfare, as the individual, not the government or anyone else, is best positioned to determine the satisfaction he derives from a good, including medical services. ${ }^{(8)}$

Robert Nozick provides an additional defence of the free market, arguing that it is ethical if it fulfils three preconditions: justice in acquisition and transfer, and in the rectification of injustice. ${ }^{(9)}$ This theory can be applied to the pricing of medical services. Assuming that the first precondition holds in that medical skills and property rights for medical equipment are fairly acquired, as long as there is justice in transfer where individuals voluntarily agree to pay for medical treatment, then any free market price, however exorbitant, is just.

As was noted in Rebecca Chew's critique of the Lim Mey Lee Susan vs. Singapore Medical Council case, greater transparency in pricing amongst Singapore's doctors should entail less legal intervention since patients are "fully aware" and intentionally choose the overcharging doctor in spite of cheaper alternatives, ${ }^{(10)}$ fulfilling Nozick's second precondition of justice in transfer and thus obviating the need for rectification in terms of legal intervention.

\section{HEALTH AS A HUMAN RIGHT}

The United Nations defines the right to health as an essential human right. ${ }^{(11)}$ As a human right, accessibility to healthcare is seen as a necessity and may supersede free market considerations. Economist Amartya Sen elaborates on this, introducing the concept of 'unfreedom', which he describes as a lack of freedom. Sen argued that economic prosperity is essential for traditional liberty, such as personal freedoms, as poverty can result in individuals falling prey to other violations of freedoms. ${ }^{(12)}$ This is because a lack of economic freedom restricts access to - or the liberty to choose - certain essential medical treatments that are vital to maintaining health. Hence, keeping healthcare affordable assists in self-actualisation and helps to support personal choices. This, in turn, upholds human dignity.

Additionally, the idea of very affordable - or even free healthcare is consistent with John Rawls' theory of social justice, which entails equality of both opportunity and outcome. Norman Daniels argues that access to healthcare is fundamental to equality of opportunity as good health is needed for an individual to enjoy the "normal range of opportunities" afforded in a free society. ${ }^{(13)}$ Healthcare is also essential to achieve equality of outcome, as many genetic or infectious diseases are acquired through no fault of the patient. Therefore, similar to gifts and talents, sickness and health are independent of moral effort, and hence are morally arbitrary.

${ }^{1}$ Department of Geriatric Medicine, Khoo Teck Puat Hospital, Singapore

Correspondence: Dr Philip Yap, Senior Consultant, Department of Geriatric Medicine, Khoo Teck Puat Hospital, 90 Yishun Central, Singapore 768828. yap.philip.Ik@alexandrahealth.com.sg 
A belief in healthcare as a human right and the need to ensure accessible healthcare to maintain social equity has resulted in some countries offering free healthcare, one of the most wellknown being the National Health Service (NHS) in Britain, ${ }^{(14)}$ although there has been criticism over its long waiting times and the high costs to the state in running the NHS.

\section{MORAL DUTY OF PHYSICIANS}

Physicians' sway over patients' health and lives creates the risk of discretionary exploitation, which arises when parties in a transaction are unequal in position and power. ${ }^{(15)}$ Coercion may result, especially if the patient's health restricts the capacity to give informed consent, and the physician can induce the patient to pay expensive fees for treatment. This possibility has become more real today as with doctors' increasing specialisation, it is more likely that one physician may monopolise proceedings in certain subspecialties. Given that physicians have a moral duty to heal patients and patients are morally deserving of treatment, such discretionary exploitation takes unfair advantage of patients, using them as a means to an end. This also violates Immanuel Kant's second formulation of the categorical imperative that each individual, as a rational agent, is an 'end'. Robert Audi interprets this as a command not to disregard the individual's well-being. ${ }^{(16}$ This concept dovetails with the two pillars of medical ethics: beneficence and non-maleficence. A non-exploitative exchange would entail fair compensation for the physician's time during treatment, opportunity cost in providing this treatment, and the effort he expended in acquiring and honing medical skills.

\section{A NEW MORAL COMPACT}

Singer, citing Titmuss, acknowledges the difficulty in comparing commerce against altruism as it is a choice between "two different types of society". ${ }^{(17)} \mathrm{A}$ similar argument can apply when comparing doctors' ethical and commercial choices. Doctors, on the one hand, have a commercial obligation to the companies that hire them to bring in profits, especially those in private practice; on the other, they have a moral duty to save patients.

In Milton Friedman's words, "The business of business is business". Corporations are amoral as they are purely artificial legal entities that lack the moral and social responsibilities of people; hence, their primary social role is the maximisation of profit for shareholders. Doctors, as agents of corporations, are beholden to fulfilling the objective of their principal - firms. Friedman argues that if employees of these firms wish to exercise their moral responsibilities to the poor or disadvantaged, they can do so in their personal, not professional, capacities and become principals. ${ }^{(18)}$ For doctors, this may mean volunteering their services pro bono.

However, this does not preclude doctors and firms from charging patients a reasonable price for their services, especially since many doctors own their practices and hence are principals. The price should take into account both the cost in providing treatment and patients' ability to pay. By this token, charging wealthy patients higher rates may not be construed as exploitative. For instance, Dr James Andrew's reconstruction surgery rates do not qualify as discretionary exploitation given that his surgeries have garnered world-class athletes billions in earnings from contracts through their speedy recovery. ${ }^{(19)}$ Is he not entitled to a share of their income from his efforts? Importantly, his rates do not hamper his well-heeled clients' access to healthcare; that is, their right to health is not infringed on. In the ideal scenario, doctors exercise a degree of price discrimination, using income from wealthy patients to cross-subsidise the treatments of lower-income patients.

Researcher Robert Hare has proposed two different levels of moral reasoning, the critical and the intuitive. ${ }^{(17)}$ On a critical level, there is ethical justification for differentiated pricing based on the purchasing power of patients. However, on an intuitive level, it is unrealistic for doctors to evaluate every patient's wealth to determine a fair price. Hence, regulations and moral rules of thumb are needed to help guide decision-making.

\section{ETHICAL GUIDELINES}

The difficulties of setting an ethical price are multifold: the risks of shortages and the creation of a black market if a price is set too low; risks of falling afoul of antitrust laws due to excessive regulation; ${ }^{(20)}$ and the need for constant updating to reflect changing economic circumstances and social expectations.

Instead, a moral price can be set based on some overarching principles. Firstly, an adaptation of Kant's second formulation on not using individuals as a means to an end. Patients should, thus, not be used as a means for physicians to gain fame or fortune, but treated for their own sake as individuals whose lives have moral value. This ethical reasoning can be defended on grounds of basic human decency, as well as the idea of 'moral luck': the patient may happen to be wealthy and have access to healthcare, but this does not make the intent to exploit moral or just. Hence, for physicians, both intent and outcome are vital in ensuring quality care for patients.

Secondly, there can be an emphasis on Rawls' difference principle, which tolerates inequality only when it benefits the worst-off in society. ${ }^{(21)}$ An example of such acceptable inequality would be if price inequality facilitates healthy competition amongst doctors to the degree that it results in improvements in standards that raise the general quality of care. Of course, a fundamental precondition for such healthy competition would be patients' understanding of the appropriate price and differences in standards between physicians. Only then can there be 'valuebased competition', as famously promoted by Michael E Porter, whereby unrestricted competition promotes an increase in value for patients, rather than simply lowering costs. ${ }^{(22)}$

\section{CONCLUSION}

On the regulation of healthcare pricing, it is prudent to heed Singer's observation about the tenacity of the free market. Even in command economies like the Soviet Union, economic selfinterest exerted itself through corruption and bribery. ${ }^{(17)}$

No amount of regulation can eliminate the element of selfinterest, which is intrinsic to the human condition. Moreover, excessive regulation can have detrimental effects on the provision of services due to potential market distortions and uncertainties. 
From a utilitarian perspective, this has profound negative implications for a good as essential and life-saving as healthcare. Therefore, it is perhaps best to leave pricing to moral suasion, except for the most egregious violations, such as when a doctor knowingly misrepresents his services or commits fraud.

\section{REFERENCES}

1. Titmuss RM. The Gift Relationship: From Human Blood to Social Policy London: George Allen and Unwin, 1970.

2. Arrow K. Gifts and exchanges. Philos Public Aff 1972; 1:343-62.

3. Singer P. Altruism and commerce: a defense of Titmuss against Arrow. Philos Public Aff 1973; 2:312-20.

4. Press Trust of India. Drug regulator slaps penalty on Novartis for overcharging painkiller. In: The Indian Express [online]. 2014 Oct 14 Available at: http://indianexpress.com/article/business/companies/drugregulator-slaps-penalty-on-novartis-for-overcharging-painkiller/. Accessed December 14, 2014.

5. Hu E. When doctors overcharge, what price do they pay? In: Singapore Law Review [online]. Available at: http://www.singaporelawreview. org/2013/09/when-doctors-overcharge-what-price-do-they-pay/. Accessed December 14, 2014.

6. Tan CC. Doctor's fees: what has changed after the Susan Lim case? SMA News 2013 September. Available at: https://www.sma.org.sg/ UploadedImg/files/Publications\%20-\%20SMA\%20News/4509/Insight. pdf. Accessed January 5, 2014.

7. Gray J. Does the free market corrode moral character? In: John Templeton Foundation [online]. Available at: http://www.templeton.org/market/PDF/ Gray.pdf. Accessed January 5, 2015.

8. Mills JS. On Liberty. London: Electric Book Company, 2001.

9. Nozick R. Anarchy, State, and Utopia. New York: Basic Books, 1974.

10. Chew R. Doctor's fees after Susan Lim's case-implications for the medical profession. In: SMA News 2013 November. Available at: https://www. sma.org.sg/UploadedImg/files/Publications\%20-\%20SMA\%20News/4511/ Insight.pdf. Accessed January 5, 2015.
11. Office of the United Nations High Commissioner for Human Rights, World Health Organisation. The Right to Health, Fact Sheet Number, 2013. Available at: http://www.ohcr.org/Documenrs/Publications/Factsheet31. pdf. Accessed January 4, 2015.

12. Chimni B. The Sen Conception of Development and Contemporary International Law Discourse: Some Parallels. In: The Law and Development Review [online]. Available at: http://www.jnu.ac.in/SIS/MakingSISVisible/ Publications/Sen\%20Conception\%20of\%20Development \%20as\%20 Freedom\%20BSChimni.pdf. Accessed December 27, 2014.

13. Daniels N. Justice, Health, and Health Care. Available at: http://www. hsph.harvard.edu/benchmark/ndaniels/pdf/justice_health.pdf. Accessed December 24, 2014.

14. National Health Service (NHS). The NHS Constitution: the NHS belongs to us all. Available at: http://www.nhs.uk/choiceintheNHS/Rightsandpledges/ NHSConstitution/Documents/2013/the-nhs-constitution-for-england-2013. pdf. Accessed December 23, 2014.

15. Mayer R. Sweatshops, Exploitation, and Moral Responsibility. J Soc Philos 2007; 38:605-19.

16. Hooker B. Kant's Normative Ethics. In: Richmond J Philos 1 [online]. Available at: http://www.richmond-philosophy.net/rjp/back_issues/ rjp1_hooker.pdf. Accessed December 24, 2014.

17. Singer P. Practical Ethics, 2nd ed. London: Cambridge University Press, 1993.

18. Friedman M. The Social Responsibility of Business is to Increase its Profits. In: The New York Times Magazine. Available at: http://www.umich. edu/ thecore/doc/Friedman.pdf. Accessed December 23, 2014

19. Rovell D. Is Dr. James Andrews The Most Valuable Person In Sports? In: Sports Biz with Darren Rovell [online]. Available at: http://www.cnbc. com/id/36690451. Accessed December 24, 2014.

20. Grad FP. The antitrust laws and professional discipline in medicine. Duke Law J 1978:443-86.

21. Lacewing M. Rawls and Nozick on Justice. Available at: http://documents. routledge-interactive.s3.amazonaws.com/9781138793934/A2/Political/ JusticeRawlsNozick.pdf. Accessed December 27, 2014.

22. Porter ME. Value-Based Competition in Health Care. Available at: http:// www.upenn.edu/ldi/porterslides.pdf. Accessed April 4, 2014 